\title{
A spatiotemporal study of bacterial community profiles associated with Atlantic bluefin tuna larvae, Thunnus thynnus L., in three Mediterranean hatcheries
}

\author{
François-Joël Gatesoupe ${ }^{1, ~}$, Denis Covès ${ }^{2}$, Aurelio Ortega ${ }^{3}$, Nikos Papandroulakis ${ }^{4}$, Olav Vadstein ${ }^{5}$, \\ Fernando de la Gándara ${ }^{3}$
}

\footnotetext{
1 INRA, UR 1067, 'Nutrition, Métabolisme, Aquaculture', Ifremer, Centre de Brest, Laboratoire ARN, Plouzané, France

${ }^{2}$ Laboratoire Aquacole du Languedoc Roussillon, Ifremer, UMR 110, Intrepid, 'INtensification Raisonnée et Ecologique pour une PIsciculture Durable', Palavas, France

${ }^{3}$ Centro Oceanográfico de Murcia, Instituto Español de Oceanografía (IEO), Puerto de Mazarrón, Spain

${ }^{4}$ Institute of Aquaculture, Hellenic Center for Marine Research (HCMR), Heraklion, Greece

${ }^{5}$ Department of Biotechnology, Norwegian University of Science and Technology (NTNU), Trondheim, Norway

*: Corresponding author : François-Joël Gatesoupe, email address : Joel.Gatesoupe@ifremer.fr
}

\begin{abstract}
:
During the first 2 years of larval rearing trials with Atlantic bluefin tuna, survival was a challenging issue. As bacterial colonization of the gut has been shown to play a key role for other species, we studied the profiles of the microbiota associated with individual larvae at different stages in three distant hatcheries. The Bacterial Community Profile (BCP) was quantified based on PCR-DGGE analyses of partial amplicons from 16S rDNA. Considerable individual variability in BCP was observed before onset of feeding, and the BCP did not show regular fluctuation during ontogenesis. Microalgae were added to the rearing tanks in two of the three hatcheries, but it was not possible to distinguish the effect of location from the effect of algal addition on BCP. In one hatchery, the larvae were reared either with algal addition or in mesocosm, but due to high individual variability, no significant difference in BCP was detected between the two groups. It was hypothesized that this variability was caused by differences in health, physiological status and developmental stage of the larvae. A practical conclusion from the study is the need to analyse a considerable number of individuals to reflect statistically significant differences between the microbial communities associated with rearing groups.
\end{abstract}

Keywords : larval rearing; bacterial diversity; DGGE; Thunnus thynnus 
Due to the collapse of bluefin tuna recruitment in western Atlantic Ocean (Safina \& Klinger, 2008), the effort to develop methods for reproduction in captivity was initiated (Mylonas, de La Gándara, Corriero \& Belmonte Ríos, 2010). The first attempts of larval rearing were recently published with the conclusion that further research on environmental factors and nutritional requirements are required to improve survival at early stages (de la Gándara, Mylonas, Covès, Ortega, Bridges, Belmonte Ríos, Vassallo-Agius, Papandroulakis, Rosenfeld, Tandler, Medina, Demetrio, Corriero, Fauvel, Falcon, Sveinsvoll, Ghysen, Deguara \& Gordin, 2010; de Metrio, Bridges, Mylonas, Caggiano, Deflorio, Santamaria, Zupa, Pousis, Vassallo-Agius, Gordin \& Corriero, 2010). Makridis, Papandroulakis, Sarropoulou \& Divanach (2011) observed proliferation of bacteria associated to moribund tuna larvae. It is essential to document bacterial colonization in this new species, as microbiota-host interaction may develop into parasitic infection in fish larvae, and thus cause mortality (Olafsen, 2001; Vadstein, Mo \& Bergh 2004).

The recent studies on microbial community structure in fish are based on cultureindependent methods, but deal mainly with cold-water species. For example, the Bacterial Community Profile (BCP) associated with Atlantic halibut was distinct from that of the surrounding water, but with similarities between larvae sampled in different geographical regions (Jensen, Øvreås, Bergh \& Torsvik, 2004). The succession of BCP was similar in batches of larvae sampled over several years, despite variable BCP in the live feeds (Plante, Pernet, Hache, Ritchie, Ji \& Mclntosh, 2007; Mclntosh, Ji, Forward, Puvanendran, Boyce \& Ritchie, 2008). However, feeds and other factors influenced BCP associated with fish larvae in other studies (Bjornsdottir, Karadottir, Johannsdottir, Thorarinsdottir, Smaradottir, Sigurgisladottir \& Gudmundsdottir, 2010; Lauzon, Gudmundsdottir, Petursdottir, Reynisson, Steinarsson, Oddgeirsson, Bjornsdottir \& Gudmundsdottir, 2010). This is complicated further by the fact that BCP varied almost as much between individuals from the same tank as between different hatcheries and rearing systems for cod larvae (Fjellheim, Playfoot, Skjermo \& Vadstein, 2007; Fjellheim, Playfoot, Skjermo \& Vadstein, 2011).

There is less data available on BCP based on culture-independent methods for temperate and warm water marine fish larvae, even though microbial management is considered essential also for Mediterranean hatcheries (Dimitroglou, Merrifield, Carnevali, Picchietti, Avella, Daniels, Güroy \& Davies, 2011). The relatively high temperature required by tuna larvae may exacerbate bacterial growth in the larval rearing tanks (Nakagawa, Eguchi \& Miyashita, 2007). The addition of microalgae to the rearing tanks may regulate the bacterial community, as in the "green water" (Stottrup, Gravningen \& Norsker, 1995) and the "pseudo green water" method, based on the control of light intensity, photophase and feed supply, with a daily addition of microalgae to maintaining constant their concentration in the rearing system (Papandroulakis, Divanach \& Kentouri, 2002). An alternative to intensive rearing systems is the mesocosm approach where large tanks are colonized by wild plankton populations (Van der Meeren \& Naess, 1993). In this system, bacteria proliferate after the first phytoplankton bloom, and then remain at a constant level (Pitta, Giannakourou, Divanach \& Kentouri, 1998). The mesocom approach can be combined with regular addition of cultured feed (microalgae and rotifers) to increase productivity (Divanach \& Kentouri, 2000).

One goal of the SELFDOTT project - "SELF-sustained aquaculture and DOmestication of Thunnus thynnus" - was to compare three rearing methods in common use in Mediterranean hatcheries; clear or pseudo green water in intensive rearing, or the mesocosm approach (de la Gándara et al., 2010). In this framework, it was important to study to what extent these different rearing techniques affected the colonization of individual tuna larvae by bacteria. Microbiota associated with tuna larvae were sampled at different stages in the three hatcheries during two consecutive years, with the 
objective to compare the bacterial community profiles in individuals sampled within and among the rearing groups. The BCP was characterized by PCR-DGGE (Denaturing Gradient Gel Electrophoresis), and intended to evaluate the stochasticity of bacterial colonization in tuna larvae (Fjelheim et al. 2011).

\section{Materials and Methods}

\subsection{Larval rearing and sampling}

The eggs were obtained from ABFT broodstock of Caladeros del Mediterráneo (S.A., Cartagena, Spain), and split in three and transported to the different hatcheries. One part was incubated at IEO (Puerto de Mazarrón, Spain; Ghysen, Schuster, Covès, de la Gándara, Papandroulakis \& Ortega, 2010), and the larvae were reared in pseudo green water in the local facilities. A second part of the eggs were and shipped to Ifremer (Palavas, France), where the larvae were reared in clear water. The last third was sent to HCMR (Heraklion, Greece), where the larvae were reared in two conditions - pseudo green water and mesocosm. The initial numbers of larvae are reported in Table1. The pseudo green water techniques and the mesocosm system differed mainly in the initial concentration of larvae, tank size, illumination, and water quality and dynamics. The pseudo green water techniques differed between Mazarrón and Heraklion in terms of algal supply, feed sequence and enrichment.

The PCR-DGGE analysis was done on individual larvae, which came from Mazarrón and Palavas in 2009, and from all three hatcheries in 2010. Larvae were collected at 2 or $3 \mathrm{dph}$ (day post hatch), and at 7,10 or $12 \mathrm{dph}$. The mean lengths of the larvae and the size of the samples are reported on Table 2. Two batches of larvae were sampled at 3 dph in Palavas in 2009. In 2010, larvae were sampled at 3 and 15 dph in Mazarrón and Palavas. In addition, two larvae were sampled at 20 dph at Mazarrón in 2010. All the larvae were fixed immediately in RNAlater (Applied Biosystems, Courtaboeuf, France), and then stored at $-20^{\circ} \mathrm{C}$.

\subsection{DNA extraction}

A method of DNA extraction adapted after Godon, Zumstein, Dabert, Habouzit \& Moletta (1997) secured enough bacterial DNA from individual tuna larvae even at 2-3 dph. All chemicals were of molecular biology grade and were purchased from SigmaAldrich (Saint-Quentin Fallavier, France). The individuals were picked up from the RNAlater solution, and distributed to $2 \mathrm{ml}$ Eppendorf tubes with $250 \mu \mathrm{l}$ of inhibiting buffer (4 M guanidine thiocyanate, $0.1 \mathrm{M}$ Tris, $\mathrm{pH}$ 7.5). The samples were homogenized with a dispersing aggregate unit, and incubated at $70^{\circ} \mathrm{C}$ for $1 \mathrm{~h}$ in extraction buffer $(40 \mu \mathrm{l}$ of $10 \% \mathrm{~N}$-lauroyl sarcosine, plus $500 \mu \mathrm{l}$ of $5 \% \mathrm{~N}$-lauroyl sarcosine, $0.1 \mathrm{M}$ phosphate buffer, $\mathrm{pH}$ 8.0). After cooling, the tubes were vortexed at maximum speed for $10 \mathrm{~min}$ with $250 \mu \mathrm{l}$ of acid-washed silica beads (0.1-mm diameter). PCR inhibitors were removed with $15 \mathrm{mg}$ Polyvinylpolypyrrolidone. The supernatant was retained after centrifugation at $18,000 \mathrm{~g}$ for $3 \mathrm{~min}$, and the pellet was washed three times with $500 \mu \mathrm{l}$ of buffer $(50 \mathrm{mM}$ Tris $\mathrm{pH} 8,20 \mathrm{mM}$ EDTA pH 8, $100 \mathrm{mM} \mathrm{NaCl}, 1 \%$ polyvinylpolypyrrolidone). The pooled supernatants were centrifuged again at $18,000 \mathrm{~g}$ for $3 \mathrm{~min}$, and split in two. After addition of $1 \mathrm{ml}$ isopropanol to each 1 -ml fraction and centrifugation at $18,000 \mathrm{~g}$ for $90 \mathrm{~min}$, the pellets were re-suspended in $225 \mu \mathrm{l}$ of 100 $\mathrm{mM}$ phosphate buffer $(\mathrm{pH} 8)$ and $25 \mu \mathrm{l}$ of $5 \mathrm{M}$ potassium acetate. After centrifuging again at $18,000 \mathrm{~g}$ for $30 \mathrm{~min}$, the supernatants from these two centrifugations were 
pooled and incubated at $37^{\circ} \mathrm{C}$ for 30 min with $2 \mu$ of RNase $\left(10 \mathrm{mg} \mathrm{ml}^{-1}\right)$. After precipitation in $1 \mathrm{ml}$ of absolute ethanol and $50 \mu \mathrm{l}$ of $3 \mathrm{M}$ sodium acetate, the DNA pellet was recovered by centrifugation at $18,000 \mathrm{~g}$ for $30 \mathrm{~min}$. The pellet was washed twice with $75 \%$ ethanol, and once with absolute ethanol (5 min centrifugation), let dry, and re-suspended in $50 \mu \mathrm{l}$ of autoclaved 'Mili-Q' water. The DNA concentration and the purity were estimated with NanoDrop (Wilmington, DE, USA). If the total DNA concentration was less than $200 \mathrm{ng} \mathrm{\mu l}^{-1}$, the sample was treated with OneStep PCR Inhibitor Removal Kit (Zymo Research, Irvine, CA, USA.).

\subsection{PCR of $16 S$ rDNA, and DGGE}

It was possible to obtain amplification by using universal bacterial primers in the presence of high amounts of eukaryotic DNA in the samples, with a method of nested PCR adapted from Bakke, de Schryver, Boon \& Vadstein (2011). When total DNA

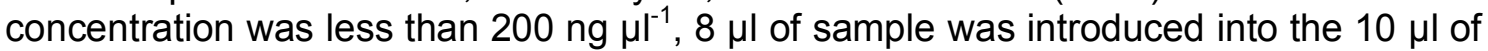
total PCR mix for the first round of the nested PCR. When there was more than $200 \mathrm{ng}$ DNA $\mu^{-1}$ in the extract, $1 \mu \mathrm{l}$ of sample was added to the PCR mix, which was

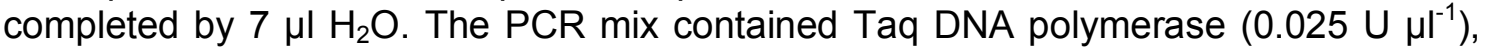
$0.2 \mathrm{mM}$ of each dNTP, $0.4 \mu \mathrm{M}$ of each primer (EUB-8-f; 984-r), and $2 \mathrm{mM} \mathrm{MgCl}_{2}$ (initial denaturation at $95^{\circ} \mathrm{C}$ for $5 \mathrm{~min} ; 35$ cycles of $30 \mathrm{~s}$ denaturation at $95^{\circ} \mathrm{C}, 30 \mathrm{~s}$ annealing at $48^{\circ} \mathrm{C}$, and $1 \mathrm{~min}$ elongation at $72^{\circ} \mathrm{C}$; final extension at $72{ }^{\circ} \mathrm{C}$ for $10 \mathrm{~min}$ ). The second round restricted the amplicon to the variable region $\mathrm{V} 3$, with a GC clamp added for DGGE (ca. $180 \mathrm{bp}$; primers 338-f-GC and 518-r). $3 \mu \mathrm{l}$ of PCR product from the first round was added to the PCR mix $\left(30 \mu l\right.$ in total; initial denaturation at $95^{\circ} \mathrm{C}$ for $5 \mathrm{~min}$; 30 cycles with $30 \mathrm{~s}$ at $95^{\circ} \mathrm{C}, 30 \mathrm{~s}$ at $53^{\circ} \mathrm{C}$, and $1 \mathrm{~min} 72^{\circ} \mathrm{C}$; final extension at $72^{\circ} \mathrm{C}$ for $30 \mathrm{~min})$.

Twenty-five $\mu \mathrm{l}$ of PCR product were loaded onto a $8 \%$ polyacrylamide gel prepared from $40 \%(\mathrm{w} / \mathrm{v})$ acrylamide/N, N'-methylenebisacrylamide (37.5:1). The denaturing gradient was prepared by mixing 35 and $60 \%$ solution of $7 \mathrm{M}$ urea and $40 \%$ formamide with the gradient maker provided with INGENYphorU (Ingeny International, Goes, The Netherlands). Fourteen gels were successively prepared to compare two or more groups on the same gel. The compared groups differed by either the age of the larvae, the batch, the hatchery, the rearing system, or the year of sampling (Gels I-XIV, Table 3). The electrophoreses were run for $18 \mathrm{~h}$ at $80 \mathrm{~V}$ and $60^{\circ} \mathrm{C}$ in the phorU system, filled with 1 X TAE buffer. However, only Gels I and XIV were cast in the phorU cassette. The 'sandwich core' unit of DCode (Bio-Rad, Marnes-la-Coquette, France) was preferred to improve linear migration on the other gels. The gels were stained for $30 \mathrm{~min}$ in $200 \mathrm{ml}$ of TAE solution with SYBR Green I $\left(0.1 \mu \mathrm{m} \mathrm{ml}^{-1}\right)$. After rinsing, the band pattern was visualized by scanner (Typhoon 9400, Amersham Biosciences, Uppsala, Sweden).

\subsection{Gel image analysis and statistics}

The images of the 14 gels were analysed with GelCompar II (version 6.1, Applied Maths, Sint-Martens-Latem, Belgium) for band alignment and quantification of peak areas. The percent normalized data were further analysed with the Paleontological Statistics Software Package (PAST; Hammer, Harper \& Ryan, 2001). Pairwise BrayCurtis similarities were calculated between lanes on each gel. This index is robust and well suited for relative data (Field, Clarke \& Warwick, 1982; Anderson, Crist, Chase, Vellend, Inouye, Freestone, Sanders, Cornell, Comita, Davies, Harrison, Kraft, Stegen \& Swenson, 2011). The Bray-Curtis similarities within and between the groups of samples were compared by one-way Non-Parametric Multivariate ANalysis Of VAriance (NPMANOVA; Anderson, 2001). For each sample the diversity indices were computed based on band pattern. When a sample was analysed several times on the 14 gels, the inter-gel average was calculated. These averages were used for 
comparisons of diversity between samplings using ANOVA for cases where the requirement of normality and equality of variance were met, and with the Kruskal-Wallis test when these requirements were not met. Pairwise comparisons were done with Tukey or Dunn's test, respectively. When only two groups were compared, the Student t or Mann-Whitney test was used.

\section{Results}

The intra-group median Bray-Curtis similarity in the microbiota of individual larvae are presented in Table 3, and statistical analysis based on Bray-Curtis similarities between the hatcheries, the developmental stage of larvae, and the year of sampling are reported in Tables 4, 5 and 6, respectively.

The median Bray-Curtis similarity of one group varied between different gels (Table 3 ). This was partly due to the fact that different gels were represented by different individuals, and partly due to gel-to-gel variability. Medians around 0.3 were observed for the larval groups with the lowest intra-group similarities, indicating a large individual variability within these groups. The highest intra-group similarities were mainly observed at mouth opening in 2009 in Mazarrón (0.80 in Gels I and II, and 0.87 and in Gel IX) whereas the medians were more variable in Palavas (0.42-0.76). In 2010 the medians at mouth opening were lower in Mazarrón, compared with the groups from the two other hatcheries (0.32-0.48 in Mazarrón, versus 0.60-0.72 in the two others). After onset of feeding the median similarities within groups were more variable and in general lower than at mouth opening.

The variability between groups was mostly higher than the variability within groups. In fact significant differences were observed for all the gels except Gel XII (NPMANOVA, Table 3). This latter gel compared samples collected from the pseudo green water and mesocosm systems at $10 \mathrm{dph}$ in Heraklion. The lack of significant difference in the microbiota between these two rearing systems was confirmed on Gels IV, V, and XI by pairwise Bonferroni multiple comparison ( $P=1,0.19$ and 1, respectively). This was due to very different DGGE band patterns of individuals within the same group, resulting in low intra-group similarity (e.g. Gel XI, Fig. 1).

When comparing Bray-Curtis similarity between hatcheries within the same gel, significant differences were found for all 9 possible comparisons at the same developmental stage (Table 4).

The groups collected at two different stages in the same hatchery and in the same year had significantly different BCP, except at Mazarrón (Gels I and VI; Table 5). However, only two individuals were sampled at $20 \mathrm{dph}$, and thus a reliable conclusion about BCP is not possible for this developmental stage.

Significant differences in BCP were detected between years for the larvae collected at Palavas and Mazarrón (Table 6). At Palavas a significant difference was detected at mouth opening between the two experimental groups in 2009. In Mazarrón the BCP of the group sampled at $12 \mathrm{dph}$ in 2009 was significantly different from those of both groups sampled in 2010 at 10 and 15 dph (Fig. 2).

The individual variations in bacterial diversity indices, and statistical comparisons between groups at the same age are presented in Table 7. At mouth opening the mean dominance index was higher at Palavas in 2009 compared to the samples from 2010 at Palavas and Mazarrón. The band richness was higher at Palavas in 2010 compared with the second batch of 2009 and with Mazarrón in 2009. In these two hatcheries the Shannon's entropy in 2009 was lower than in 2010. The greatest difference in evenness was observed between the two years at Palavas. Comparisons of diversity indices in 2010 at 10 dph revealed that the mean dominance at Palavas was higher than at Heraklion, where no significant difference was found between the mean diversity indices of the two rearing systems. The band richness and the Shannon's entropy at Heraklion were low compared to the two other hatcheries. At 15 dph in 2010 
there were significant differences between Palavas and Mazarrón in dominance, band richness, and Shannon's entropy.

The mean dominance, band richness and Shannon's entropy differed between the stages of development at Mazarrón in 2010, but this was due to the fact that only two individuals were sampled at $20 \mathrm{dph}$. These two larvae had lower diversity than larvae sampled at earlier stages (Fig. 3). In Heraklion, the band richness at mouth opening was higher than at $10 \mathrm{dph}$. At Palavas in 2010, the evenness was higher at $15 \mathrm{dph}$ compared with the earlier samples.

\section{Discussion}

We restricted deliberately the comparison of the similarity in DGGE band profiles to intra-gel comparisons, as the inter-gel comparisons may result in biased conclusions (Nakatsu, 2007). However, inter-gel comparison was possible for the diversity indices, but there were not general trends of fluctuation between hatcheries, developmental stage, or year of sampling. Øvreås (2000) recommended the variable V3 region as especially suitable for the analysis of bacterial diversity by DGGE, due to its high resolution. However, the short nucleotide sequence is not optimal for phylogenetic identification, and only some well-isolated bands can be excised from the gels for reamplification and sequencing. The identification of the bacterial community associated with tuna larvae based on other methods is in progress within the frame of the SELFDOTT project. A first screening revealed dominance by Vibrionaceae and Rhodobacteriaceae in the microbiota associated with the larvae of Sarda sarda (bonito), another Scombridae, reared under the same conditions as Thunnus thynnus (Makridis et al., 2011).

The high individual variability of microbiota associated with tuna larvae seemed in good agreement with that observed in cod larvae by Fjellheim et al. (2011). In this previous study, which compared feeding larvae sampled between179 and 216 days-degrees post hatch, the similarity between microbiota of individuals from the same rearing environment was comparable to the similarity between three cod hatcheries where different rearing methods were used. These days-degrees corresponded to 7-10 dph in the present rearing conditions of tuna larvae (c. $24^{\circ} \mathrm{C}$ ). At this stage, the mean Shannon diversity index of the bacterial communities associated with tuna was between 1.9 and 2.6, which is in the same range as the mean indices estimated by Fjellheim et al. (2011) based on T-RFLP analysis of the bacterial community of cod larvae (1.7-2.3).

Unexpectedly, high diversity and individual variability appeared soon after mouth opening, when the larvae had not started exogenous feeding. The present results did not reveal any specificity in the microbiota initially colonizing tuna larvae. However, our data were obtained from the first rearing trials with this species, and with high mortality 2-3 days after mouth opening (Papandroulakis, Ortega, Covès, Vassallo Agius, Tandler, Stefanakis, Viguri, Vidal, Papadakis, de la Gándara, Ruelle, Anastasiadis, Mylonas \& Divanach, 2010). The high variability in the microbiota of individuals might be due to variable physiological status and was possibly influenced by the stochastic inoculation due to the active uptake of bacteria by larvae (Reitan, Natvik \& Vadstein, 1998).

Many reports were published on the initial colonization of fish larvae by bacteria, but very few compared results from individuals. High similarity was observed among microbiota of individuals of halibut at start feeding (Jensen et al., 2004), whereas Fjellheim et al. (2011) concluded the opposite for cod larvae as noted above. In the other studies, where several larvae were pooled to describe the bacterial community, the conclusion arose that the bacterial community composition was highly diverse in yolk sac larvae of halibut, cod, and haddock (Plante et al., 2007; McIntosh et al., 2008; Bjornsdottir, Johannsdottir, Coe, Smaradottir, Agustsson, Sigurgisladottir \& 
Gudmundsdottir, 2009) and with differences between tanks and hatcheries (Griffiths, Melville, Cook, Vincent, St. Pierre \& Lanteigne, 2001; Verner-Jeffreys, Shields, Bricknell \& Birkbeck, 2003).

McIntosh et al. (2008) noted that microbiota associated with cod larvae underwent a rapid change after hatching, which was unique for each tank, but the succession in the microbiota after start feeding appeared reproducible in two consecutive years. Plante et al. (2007) reported a similar repeatability in the succession of the microbiota in many batches of larvae reared in the same hatchery over six years. No such regular succession was observed in the preliminary results on tuna larvae. Technical improvements of the larval rearing were done between the two years of sampling, and that may account at least partly for the inter-annual differences observed in the present study. Further sampling should be planned in the forthcoming years. The data from 20 dph onwards may be worth comparing with those of earlier stages. If the observed trend with a development towards a more uniform microbiota can be confirmed, it would be in accordance with observations from other species (Plante et al., 2007; McIntosh et al., 2008).

The introduction of yolk sac sea bream larvae as live prey from $18 \mathrm{dph}$ onwards might be the reason for the apparent shift in microbiota observed at $20 \mathrm{dph}$. Most authors agreed that bacteria associated with live feed affected gut microbiota in fish larvae, but to various extents. For example, changes in microbiota occurred when halibut and cod larvae started to feed on rotifers (Verner-Jeffreys et al., 2003; Brunvold, Sandaa, Mikkelsen, Welde, Bleie \& Bergh, 2007; Mclntosh et al., 2008). However, the gut microbiota of these larvae did not reflect the bacterial community associated with the rotifers, or the highly variable microbiota of Artemia (Bjornsdottir et al., 2009; Plante et al., 2007). The bacterial community composition associated with live feed was not characterized in the present experiments, but it is likely that the individual variability observed in the microbiota of tuna larvae reflected partly what they ate. Different feeding sequences and enrichments were applied to the tuna larvae in the three hatcheries, and this might have contributed to the differences observed in the microbiota from the three locations.

The effect of rearing techniques on the bacterial community composition of the larvae was beyond the scope of this preliminary study, which aimed simply to study individual variability of the bacterial community profiles within and between different batches of larvae. The only possible comparison of rearing techniques was that of mesocosm and the pseudo green water method in Heraklion. The main difference between the techniques was the concentration of the larvae and the size of the rearing tanks, which might affect physiology and behaviour of larvae (Sloman \& Baron, 2010). However, no significant effect of rearing condition was detected. This could be due to the high individual variability within treatments and limited number of individuals analysed. Other types of treatments of Atlantic tuna larvae, like probiotics, resulted in significant changes in the bacterial balance, but further studies are needed to confirm these observations (Covès, de Vogué, Desbruyères, Dhormes, Fievet, Huelvan, Lallement, Le Gall, Ruelle, Vidal, Castex, Mazurais, Cahu \& Gatesoupe, 2011).

It is not possible to generalize our findings for Atlantic tuna from the limited set of experiments with sub-optimally reared larvae of this new species. However, it is clear that the microbiota associated with fish larvae fluctuated considerably among individuals, even when they were reared in the same tank. The present results confirm the previous findings of Fjelheim et al. (2011), and a main conclusion was that representative samples should contain many individuals. The numbers of larvae included in the samples are not always reported in the literature, and it is quite variable. For example, one to five larvae were sampled each time by Verner-Jeffreys et al. (2003) and Jensen et al. (2004). Plante et al. (2007) and Mclntosh et al. (2008) used a sample size of ten larvae per sample, whereas Romero \& Navarrete (2006) used 20 individuals of coho salmon fingerlings per sample. Pools of few individuals could lead to erroneous conclusions, and the optimal size of the samples should be estimated in future experiments. Analyses of individuals are recommended as long as the reasons 
for the individual variability are not sufficiently understood. This individual variability reflects the complex interactions between bacteria and the larvae, even at an early stage, and the factors that regulate the colonization of the gut require further research.

\section{Acknowledgments}

This work was carried out with financial support from the Commission of the European Communities, specific RTD programme of Framework Programme 7, SELFDOTT, "From capture based to self-sustained aquaculture and domestication of bluefin tuna, Thunnus thynnus" (GA 212797) coordinated by F. de la Gándara. It does not necessarily reflect the Commission's views and in no way anticipates its future policy in this area. The first and the penultimate authors are also indebted to their colleagues of the ongoing FP7 project PROMICROBE, especially I. Bakke, N. Boon, P. Bossier, P. de Schryver, K. Dierckens, C. Giatsis, and J. Morillo Perez for fruitful discussions about DGGE methodology and microbial diversity in other fish larvae.

\section{References}

Anderson M.J. (2001) A new method for non-parametric multivariate analysis of variance. Austral Ecology 26, 32-46. doi:10.1111/j.1442-9993.2001.01070.pp.x

Anderson M.J., Crist T.O., Chase J.M., Vellend M., Inouye B.D., Freestone A.L., Sanders N.J., Cornell H.V., Comita L.S., Davies K.F., Harrison S.P., Kraft N.J.B., Stegen J.C. \& Swenson N.G. (2011) Navigating the multiple meanings of $\beta$ diversity: a roadmap for the practicing ecologist. Ecology Letters 14, 19-28. doi:10.1111/j.14610248.2010.01552.x

Bakke I., de Schryver P., Boon N. \& Vadstein O. (2011) PCR-based community structure studies of Bacteria associated with eukaryotic organisms: A simple PCR strategy to avoid co-amplification of eukaryotic DNA. Journal of Microbiological Methods 84, 349-351. doi:10.1016/j.mimet.2010.12.015

Bjornsdottir R., Johannsdottir J., Coe J., Smaradottir H., Agustsson T., Sigurgisladottir S. \& Gudmundsdottir B.K. (2009) Survival and quality of halibut larvae (Hippoglossus hippoglossus L.) in intensive farming: Possible impact of the intestinal bacterial community. Aquaculture 286, 53-63. doi:10.1016/j.aquaculture.2008.09.003

Bjornsdottir R., Karadottir E.G., Johannsdottir J., Thorarinsdottir E.E., Smaradottir H., Sigurgisladottir S. \& Gudmundsdottir B.K. (2010) Selection of bacteria and the effects of bacterial treatment of Atlantic halibut (Hippoglossus hippoglossus L.) eggs and larvae. Aquaculture 302, 219-227. doi:10.1016/j.aquaculture.2010.02.026

Brunvold L., Sandaa R.A., Mikkelsen H., Welde E., Bleie H. \& Bergh Ø. (2007) Characterisation of bacterial communities associated with early stages of intensively reared cod (Gadus morhua) using Denaturing Gradient Gel Electrophoresis (DGGE). Aquaculture 272, 319-327. doi:10.1016/j.aquaculture.2007.08.053

Covès D., de Vogué B., Desbruyères E., Dhormes B., Fievet J., Huelvan C., Lallement S., Le Gall M.M., Ruelle F., Vidal M.O., Castex M., Mazurais D., Cahu C.L. \& Gatesoupe F.J. (2011) The effects of a probiotic treatment of live food organisms on the larvae of Atlantic bluefin tuna, Thunnus thynnus : microbiological and immunological criteria. In: Aquaculture Europe 2011: Mediterranean Aquaculture 2020, abstracts of the papers presented at the conference in Rhodes, Greece, October 18-21 
2011, pp. 212-213. European Aquaculture Society Special Publication, Oostende, Belgium.

de la Gándara F., Mylonas C.C., Covès D., Ortega A., Bridges C.R., Belmonte Ríos A., Vassallo-Agius R., Papandroulakis N., Rosenfeld H., Tandler A., Medina A., Demetrio G., Corriero A., Fauvel C., Falcon J., Sveinsvoll K., Ghysen A., Deguara S. \& Gordin H. (2010) Seedling production of Atlantic bluefin tuna (ABFT) Thunnus thynnus. The SELFDOTT project. In: Towards the Sustainable Aquaculture of Bluefin Tuna (ed. by S. Miyashita, K. Takii, W. Sakamoto \& A. Biswas), pp. 45-52. Kinki University Press, Wakayama, Japan. Joint International symposium of Kinki University and Setouchi town on the 40th anniversary of Pacific bluefin tuna aquaculture, October 15-16 2010, Amami, Japan. http://archimer.ifremer.fr/doc/00029/14015/ (last accessed 17 February, 2012).

de Metrio G., Bridges C.R., Mylonas C.C., Caggiano M., Deflorio M., Santamaria N., Zupa R., Pousis C., Vassallo-Agius R., Gordin H. \& Corriero A. (2010) Spawning induction and large-scale collection of fertilized eggs in captive Atlantic bluefin tuna (Thunnus thynnus L.) and the first larval rearing efforts. Journal of Applied Ichthyology 26, 596-599. doi:10.1111/j.1439-0426.2010.01475.x

Dimitroglou A., Merrifield D.L., Carnevali O., Picchietti S., Avella M., Daniels C., Güroy D. \& Davies S.J. (2011) Microbial manipulations to improve fish health and production A Mediterranean perspective. Fish Shellfish Immunology 30, 1-16. doi:10.1016/j.fsi.2010.08.009

Divanach P. \& Kentouri M. (2000) Hatchery techniques for specific diversification in Mediterranean finfish larviculture. In: Recent Advances in Mediterranean Aquaculture Finfish Species Diversification, Seminar of the CIHEAM network on Technology of Aquaculture in the Mediterranean, Zaragoza, 24-28 May 1999. Cahiers Options Méditerranéennes 47: 75-87. http://ressources.ciheam.org/om/pdf/c47/00600607.pdf (last accessed 17 February, 2012).

Field J.G., Clarke K.R. \& Warwick R.M. (1982) A Practical Strategy for Analysing Multispecies Distribution Patterns. Marine Ecology Progress Series 8, 37-52.

Fjellheim A.J., Playfoot K.J., Skjermo J. \& Vadstein O. (2007) Vibrionaceae dominates the microflora antagonistic towards Listonella anguillarum in the intestine of cultured Atlantic cod (Gadus morhua L.) larvae. Aquaculture 269, 98-106. doi:10.1016/j.aquaculture.2007.04.021

Fjellheim A.J., Playfoot K.J., Skjermo J. \& Vadstein O. (2011) Inter-individual variation in the dominant intestinal microbiota of reared Atlantic cod (Gadus morhua L.) larvae. Aquaculture Research (online: 12 SEP 2011) doi:10.1111/j.1365-2109.2011.02952.x

Ghysen A., Schuster K., Covès D., de la Gándara F., Papandroulakis N. \& Ortega A. (2010) Development of the posterior lateral line system in Thunnus thynnus, the Atlantic blue-fin tuna, and in its close relative Sarda sarda. The International Journal of Developmental Biology 54, 1317-1322. doi:10.1387/ijdb.103102ag

Godon J.J., Zumstein E., Dabert P., Habouzit F. \& Moletta R. (1997) Molecular microbial diversity of an anaerobic digestor as determined by small-subunit rDNA sequence analysis. Applied and Environmental Microbiology 63, 2802-2813.

Griffiths S., Melville K., Cook M., Vincent S., St. Pierre M. \& Lanteigne C. (2001) Profiling of bacterial species associated with haddock larviculture by PCR amplification 
of $16 \mathrm{~S}$ rDNA and denaturing gradient gel electrophoresis. Journal of Aquatic Animal Health 13, 355-363.

Hammer Ø., Harper D.A.T. \& Ryan P.D. (2001) PAST: Paleontological Statistics Software Package for Education and Data Analysis. Palaeontologia Electronica 4 (1): 9 pp. http://palaeo-electronica.org/2001 1/past/issue1 01.htm (last accessed 17 February, 2012).

Jensen S., Øvreås L., Bergh $\varnothing$. \& Torsvik V. (2004) Phylogenetic analysis of bacterial communities associated with larvae of the Atlantic halibut propose succession from a uniform normal flora. Systematic and Applied Microbiology 27, 728-736. doi:10.1078/0723202042369929

Lauzon H.L., Gudmundsdottir S., Petursdottir S.K., Reynisson E., Steinarsson A., Oddgeirsson M., Bjornsdottir R. \& Gudmundsdottir B.K. (2010) Microbiota of Atlantic cod (Gadus morhua L.) rearing systems at pre- and posthatch stages and the effect of different treatments. Journal of Applied Microbiology 109, 1775-1789. doi:10.1111/j.1365-2672.2010.04806.x

Makridis P., Papandroulakis N., Sarropoulou E. \& Divanach P. (2011) Microbiota in bonito (Sarda sarda) and blue fin tuna (Thunnus thynnus) larvae. In: Aquaculture Europe 2011: Mediterranean Aquaculture 2020, abstracts of the papers presented at the conference in Rhodes, Greece, October 18-21 2011, pp. 652-653. European Aquaculture Society Special Publication, Oostende, Belgium.

Mclntosh D., Ji B., Forward B.S., Puvanendran V., Boyce D. \& Ritchie R. (2008) Culture-independent characterization of the bacterial populations associated with cod (Gadus morhua L.) and live feed at an experimental hatchery facility using denaturing gradient gel electrophoresis. Aquaculture 275, 42-50. doi:10.1016/j.aquaculture.2007.12.021

Mylonas C.C., De La Gándara F., Corriero A. \& Belmonte Ríos A. (2010) Atlantic bluefin tuna (Thunnus thynnus) farming and fattening in the Mediterranean Sea. Reviews in Fisheries Science 18, 266-280. doi:10.1080/10641262.2010.509520

Nakagawa Y., Eguchi M. \& Miyashita S. (2007) Pacific bluefin tuna, Thunnus orientalis, larvae utilize energy and nutrients of microbial loop. Aquaculture 267, 83-93. doi:10.1016/j.aquaculture.2007.02.024

Nakatsu C.H. (2007). Soil Microbial Community Analysis Using Denaturing Gradient Gel Electrophoresis. Soil Science Society of America Journal 71, 562-571. doi:10.2136/sssaj2006.0080

Olafsen J.A. (2001). Interactions between fish larvae and bacteria in marine aquaculture. Aquaculture 200, 223-247. doi:10.1016/S0044-8486(01)00702-5

Papandroulakis N., Divanach P. \& Kentouri M. (2002) Enhanced biological performance of intensive sea bream (Sparus aurata) larviculture in the presence of phytoplankton with long photophase. Aquaculture 204, 45-63. doi:10.1016/S00448486(01)00643-3

Papandroulakis N., Ortega A., Covès D., Vassallo Agius R, Tandler A., Stefanakis S., Viguri J., Vidal M.O., Papadakis I., de la Gándara F., Ruelle F., Anastasiadis P., Mylonas C.C. \& Divanach P. (2010) First results of the Atlantic bluefin tuna (Thunnus thynnus) larval rearing in Europe in the frame of the Self-Dott project. In: Aquaculture Europe 2010: Seafarming Tomorrow, abstracts of the papers presented at the 
conference in Porto, Portugal, October 5-8, 2010, pp. 968-969. European Aquaculture Society Special Publication, Oostende, Belgium.

Pitta P., Giannakourou A., Divanach P. \& Kentouri M. (1998) Planktonic food web in marine mesocosms in the Eastern Mediterranean: bottom-up or top-down regulation? Hydrobiologia 363, 97-105.

Plante S., Pernet F., Hache R., Ritchie R., Ji B.J. \& Mclntosh D. (2007) Ontogenetic variations in lipid class and fatty acid composition of haddock larvae Melanogrammus aeglefinus in relation to changes in diet and microbial environment. Aquaculture 263, 107-121. doi:10.1016/j.aquaculture.2006.09.042

Reitan K.I., Natvik C.M. \& Vadstein O. (1998) Drinking rate, uptake of bacteria and microalgae in turbot larvae. Journal of Fish Biology 53, 1145-1154. doi:10.1111/j.10958649.1998.tb00238.x

Romero J. \& Navarrete P. (2006) 16S rDNA-based analysis of dominant bacterial populations associated with early life stages of coho salmon (Oncorhynchus kisutch). Microbial Ecology 51, 422-430. doi:10.1007/s00248-006-9037-9

Safina C. \& Klinger D.H. (2008) Collapse of bluefin tuna in the western Atlantic. Conservation Biology 22, 243-246. doi:10.1111/j.1523-1739.2008.00901.x

Sloman K.A. \& Baron M. (2010) Conspecific presence affects the physiology and behaviour of developing trout. Physiology \& Behavior 99, 599-604. doi:10.1016/i.physbeh.2010.01.027

Stottrup J.G., Gravningen K. \& Norsker N.H. (1995) The role of different algae in the growth and survival of turbot larvae (Scophthalmus maximus L.) in intensive rearing systems. ICES Marine Science Symposia 201, 173-186.

Vadstein O., Mo T.A. \& Bergh $\varnothing$. (2004) Microbial interactions, prophylaxis and diseases. In: Culture of cold-water marine fish,(ed. By E. Moksness, E. Kjørsvik \& Y. Olsen). pp. 28-72. Blackwell Publishing, Oxford, UK.

Van der Meeren T. \& Naess T. (1993) How does cod (Gadus morhua) cope with variability in feeding conditions during early larval stages? Marine biology 116, 637647. doi:10.1007/BF00355482

Verner-Jeffreys D., Shields R., Bricknell I. \& Birkbeck T. (2003) Changes in the gutassociated microflora during the development of Atlantic halibut (Hippoglossus hippoglossus L.) larvae in three British hatcheries. Aquaculture 219, 21-42. doi:10.1016/S0044-8486(02)00348-4

Øvreås L. (2000) Population and community level approaches for analysing microbial diversity in natural environments. Ecology Letters 3, 236-251. doi:10.1046/j.14610248.2000.00148.x 
Palavas Heraklion Mazarrón

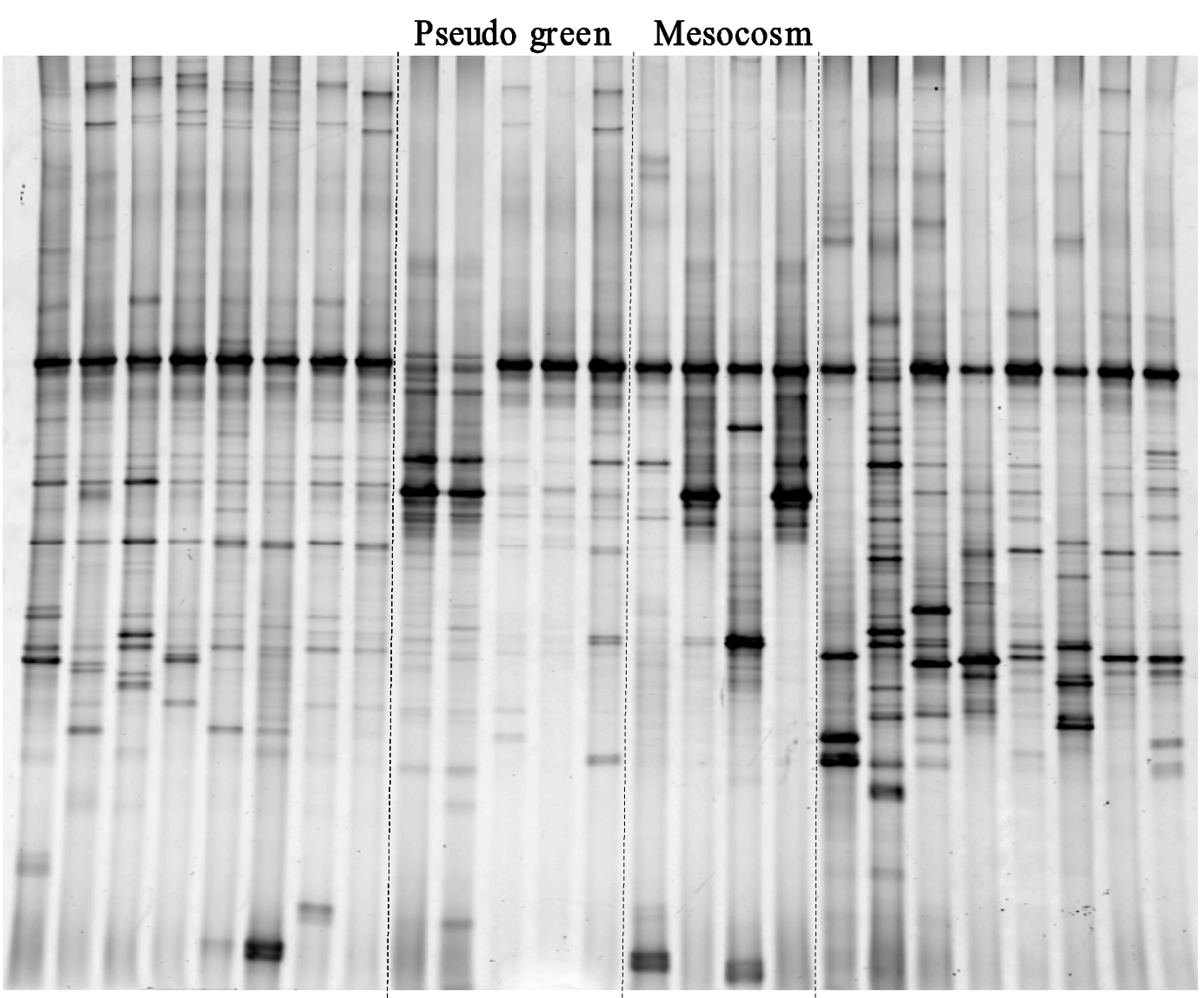

Figure 1 : DGGE profiles illustrating the individual variability observed in the bacterial community associated with individual tuna larvae sampled at $10 \mathrm{dph}$ in the three hatcheries - with two different rearing methods in Heraklion. Each lane corresponded to one larva (Gel XI). 


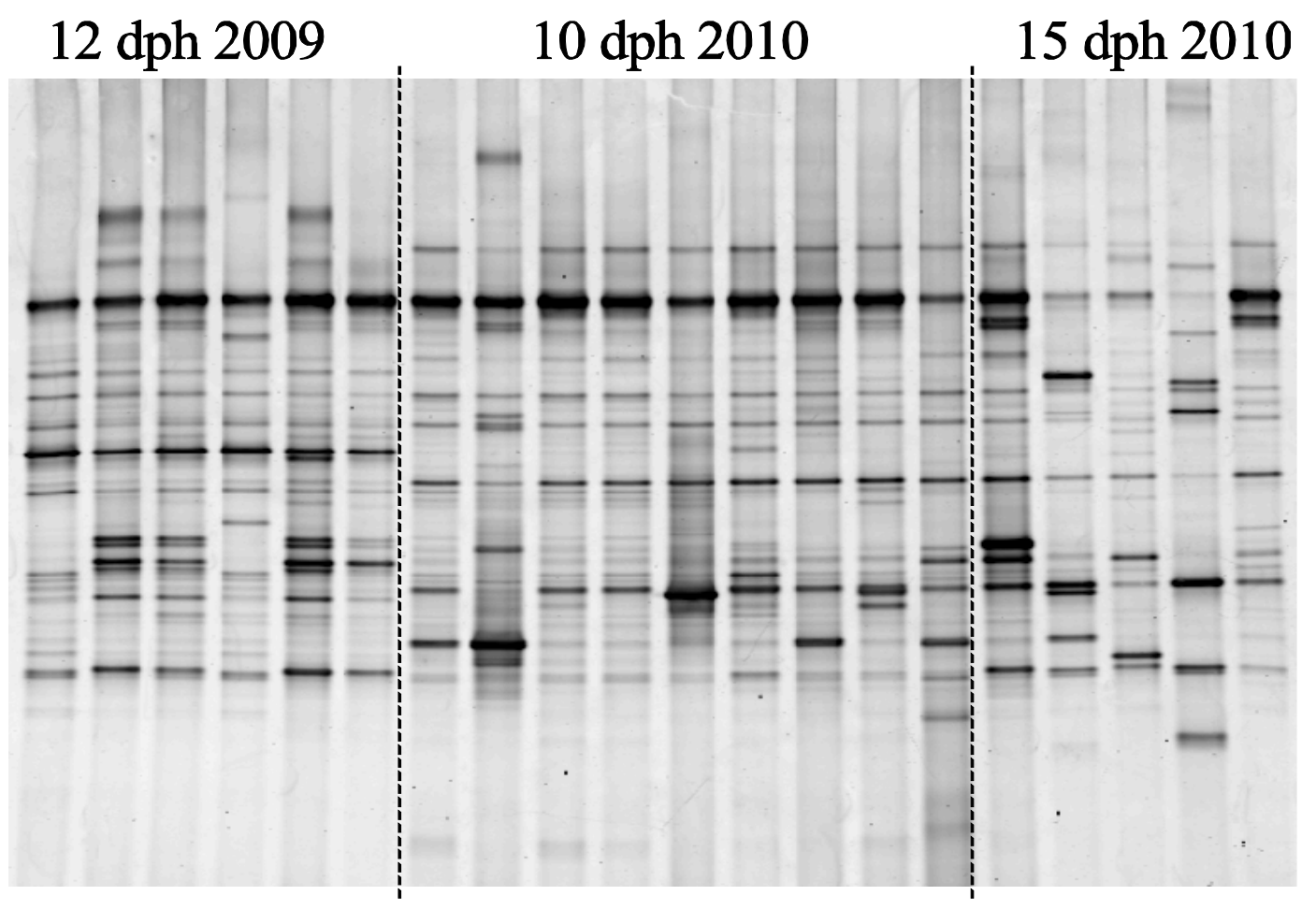

Figure 2 : DGGE profiles illustrating the individual variability observed in the bacterial community associated with individual tuna larvae sampled in two subsequent years in Mazarrón during the period of feeding on rotifers (12 dph in 2009, 10 and $15 \mathrm{dph}$ in 2010). Each lane corresponded to one larva (Gel VII). 


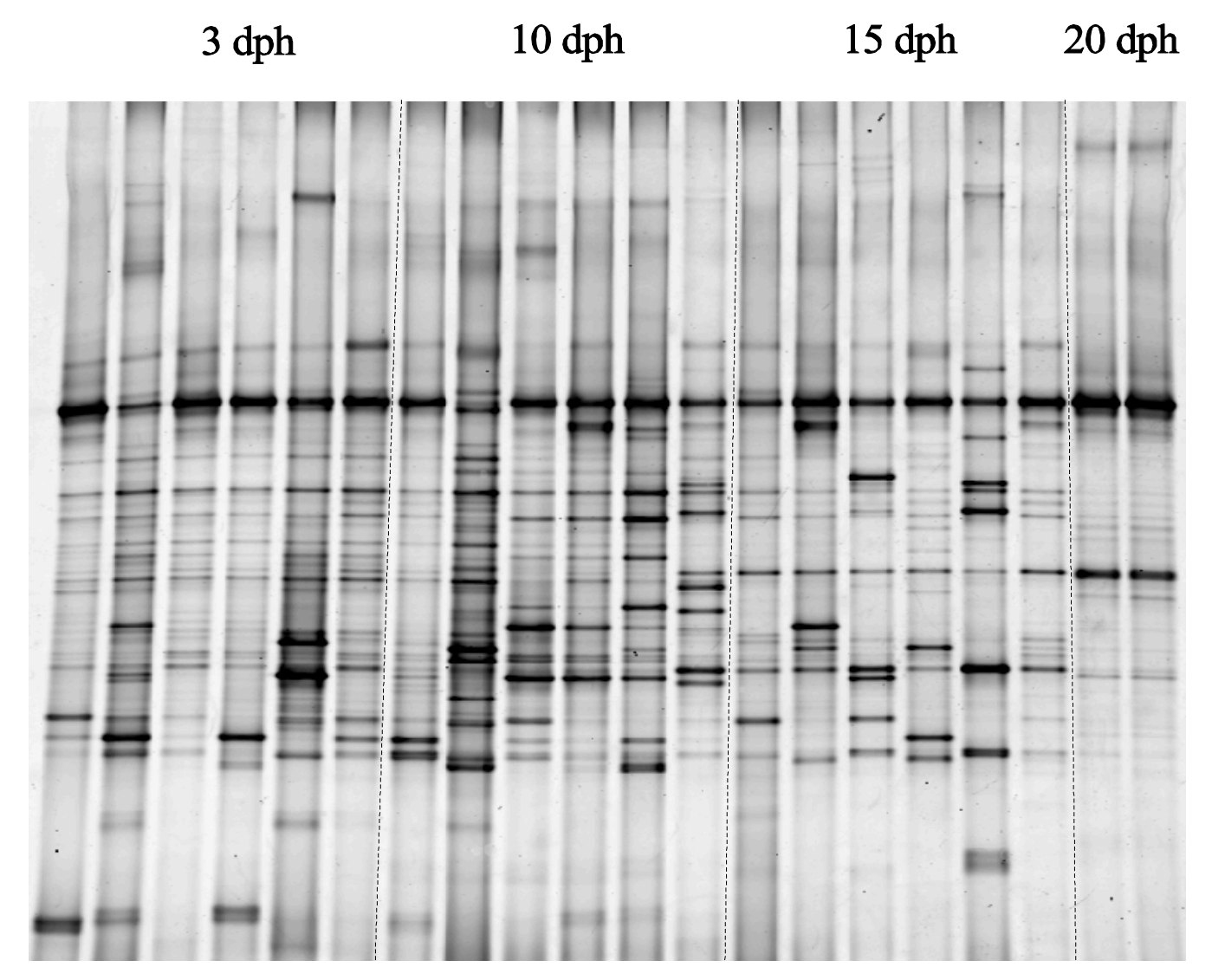

Figure 3 : DGGE profiles illustrating the succession of the bacterial community associated with individual tuna larvae from 3 to 20 dph in Mazarrón in 2010. Each lane corresponded to one larva (Gel VI). 
Tables

Table 1

Conditions for the rearing of larvae at the three hatcheries. The information is limited to the periods corresponding to the samples analysed from each hatchery (Years '09 and '10 in brackets)

\begin{tabular}{|c|c|c|c|c|}
\hline Hatchery & Palavas (clear water) & Mazarrón (pseudo green) & Heraklion (pseudo green) & Heraklion (mesocosm) \\
\hline Tank $\left(\mathrm{m}^{3}\right)$ & 0.5 & 1.5 & 0.5 & 40 \\
\hline Water origin & Sea & Sea & Borehole & Sea + borehole \\
\hline Daily renewal rate & Closed circuit & $50 \%$ & Closed circuit with $3 \%$ renewal & $1 \%$ till $8 \mathrm{dph}, 3 \%$ afterwards \\
\hline Water inlet rate $\left(\mathrm{h}^{-1}\right)$ & $25-30 \%$ & $15-20 \%$ & $20-25 \%$ & $0.042 \%$ till $8 \mathrm{dph}, 0.125 \%$ afterwards \\
\hline Temperature $\left({ }^{\circ} \mathrm{C}\right)$ & $23.5-24$ (‘09); $24.4 \pm 0.5$ (‘10) & $23-26.7$ & $24.5 \pm 1$ & $24.0 \pm 1$ \\
\hline Salinity (psu) & $36.1 \pm 1.1$ ('09); $36.6 \pm 1.0$ ('10) & 37 & 37 & $37-40$ \\
\hline $\mathrm{O}_{2}$ concentration $\left(\mathrm{mg} \mathrm{l}^{-1}\right)$ & $8.1 \pm 0.7$ & $5.3-7.2$ & $7.2 \pm 0.2$ & $7.2 \pm 0.3$ \\
\hline $\mathrm{pH}$ & $7.9 \pm 0.4$ & $7.9-8.2$ & $8.2 \pm 0.1$ & $7.9 \pm 0.2$ \\
\hline Water inlet & Bottom & Bottom & Bottom + Lateral, 'V-shaped' & Lateral \\
\hline Photoperiod (h Light: h Dark) & 24L:OD & 16L:8D & 24L:OD & 24L:OD \\
\hline Illuminance (lux) & $300-650$ & 300 & $300-600$ & $200-5000$ \\
\hline Phytoplankton & None & Nannochloropsis gaditana & Chlorella minutissima & Chlorella minutissima \\
\hline Initial concentration of larvae $\left.\right|^{-1}$ & 85 ('09); 48 ('10) & 8 & 30 & 1 \\
\hline Initial number of larvae $\left(\times 10^{3} \operatorname{tank}^{-1}\right)$ & 42.5 ('09); 24 (’10) & 12 & 15 & 40 \\
\hline Rotifer feeding period & 3-11 dph & 3-17 dph & $3 \mathrm{dph}$ onwards & 3 dph onwards \\
\hline Rotifer enrichment & Ori-Green & Ori-Green & Selco® S.pirit & Selco® S.pirit \\
\hline Artemia feeding period & $8 \mathrm{dph}$ onwards & $15-19 \mathrm{dph}$ & $8 \mathrm{dph}$ onwards & $7 \mathrm{dph}$ onwards \\
\hline Artemia enrichment & Ori-Green (13 dph onwards; '10) & Ori-Green & Selco® S.presso & Selco® S.presso \\
\hline Yolk sac sea bream larvae as prey & - & $18 \mathrm{dph}$ onwards & - & - \\
\hline Samples provided until & $7 \mathrm{dph}$ ('09); $15 \mathrm{dph}\left({ }^{\prime} 10\right)$ & 12 dph ('09); 20 dph(‘10) & $10 \mathrm{dph}\left({ }^{\prime} 10\right)$ & $10 \mathrm{dph}\left({ }^{\prime} 10\right)$ \\
\hline
\end{tabular}


Table 2

Mean length $(\mathrm{mm})$ and total number of the individuals whose bacterial community was analysed and used in comparisons, as a function of days post hatching (dph) and year of experiment for the three hatcheries,

\begin{tabular}{lcccc}
\hline & Mean length $(\mathrm{mm})$ & \multicolumn{3}{c}{ Individuals } \\
\cline { 3 - 5 } & & Mazzarón & Heraklion & Palavas \\
\hline 2009 & 4 & & & \\
$3 \mathrm{dph}$ & 5 & - & - & 28 \\
$7 \mathrm{dph}$ & 7 & 6 & - & - \\
$12 \mathrm{dph}$ & & & & \\
\hline 2010 & 4 & $10(3 \mathrm{dph})$ & $9(3 \mathrm{dph})$ & $15(2 \mathrm{dph})$ \\
Mouth opening & 6 & 10 & $20^{*}$ & 22 \\
$10 \mathrm{dph}$ & 8 & 7 & - & 25 \\
$15 \mathrm{dph}$ & 11 & 2 & - & - \\
$20 \mathrm{dph}$ & & & & \\
\hline
\end{tabular}

*10 from each condition (Pseudo green or Mesocosm) 
Table 3

Median Bray-Curtis similarity within groups based on data from the 14 DGGE gels (the numbers of individuals per group are in brackets), and results from statistical analysis by NPMANOVA for each gel ( $F$ values, and $P$ levels indicated with asterisks; n.s.: not significant).

\begin{tabular}{|c|c|c|c|c|c|c|c|c|c|c|c|c|c|c|}
\hline Gel & 1 & II & III & IV & $\mathrm{V}$ & $\mathrm{VI}$ & VII & VIII & IX & $x$ & $\mathrm{XI}$ & XII & XIII & XIV \\
\hline \multicolumn{15}{|l|}{2009} \\
\hline \multicolumn{15}{|l|}{ Palavas } \\
\hline $3 \mathrm{dph}^{\S}$ & $0.64(7)$ & $0.71(7)$ & - & - & - & - & - & - & - & - & - & - & $0.76(6)$ & $0.73(6)$ \\
\hline 3 dph ${ }^{@}$ & $0.62(7)$ & - & - & - & $0.51(6)$ & - & - & - & - & - & - & - & $0.42(6)$ & \\
\hline $7 \mathrm{dph}^{\S}$ & - & - & - & - & - & - & - & - & - & - & - & - & - & $0.39(14)$ \\
\hline \multicolumn{15}{|l|}{ Mazarrón } \\
\hline $3 \mathrm{dph}$ & $0.80(6)$ & $0.80(6)$ & - & - & - & - & - & - & $0.87(6)$ & - & - & - & - & - \\
\hline $12 \mathrm{dph}$ & $0.66(6)$ & - & - & - & $0.70(6)$ & - & $0.65(6)$ & - & - & - & - & - & - & - \\
\hline \multicolumn{15}{|l|}{2010} \\
\hline \multicolumn{15}{|l|}{ Palavas } \\
\hline $2 \mathrm{dph}$ & - & - & $0.65(9)$ & - & - & - & - & $0.71(8)$ & - & - & - & - & $0.72(7)$ & - \\
\hline $10 \mathrm{dph}$ & - & - & - & - & - & - & - & $0.54(8)$ & - & - & $0.56(8)$ & - & $0.41(6)$ & - \\
\hline $15 \mathrm{dph}$ & - & - & - & - & - & - & - & $0.84(9)$ & - & $0.48(16)$ & - & - & - & - \\
\hline \multicolumn{15}{|l|}{ Mazarrón } \\
\hline $3 \mathrm{dph}$ & - & - & $0.48(8)$ & - & - & $0.48(6)$ & - & - & $0.32(14)$ & - & - & - & - & - \\
\hline $10 \mathrm{dph}$ & - & - & - & - & - & $0.43(6)$ & $0.73(8)$ & - & - & - & $0.33(8)$ & - & - & - \\
\hline $15 \mathrm{dph}$ & - & - & - & - & - & $0.48(6)$ & $0.33(6)$ & - & - & $0.45(7)$ & - & - & - & - \\
\hline $20 \mathrm{dph}$ & - & - & - & - & - & $0.86(2)$ & - & - & - & - & - & - & - & - \\
\hline \multicolumn{15}{|l|}{ Heraklion } \\
\hline $3 \mathrm{dph}$ & - & $0.63(7)$ & $0.60(8)$ & $0.68(8)$ & - & - & - & - & - & - & - & - & & \\
\hline 10 dph Mesocosm & - & - & - & $0.47(6)$ & $0.63(4)$ & - & - & - & - & - & $0.32(4)$ & $0.48(10)$ & - & - \\
\hline 10 dph Pseudo green & - & - & - & $0.33(6)$ & $0.59(4)$ & - & - & - & - & - & $0.27(5)$ & $0.35(10)$ & - & - \\
\hline NPMANOVA & $5.4^{* * *}$ & $15.9^{\star * *}$ & $5.1^{* * *}$ & $3.9^{* * *}$ & $8.2^{* * *}$ & $2.3^{* * *}$ & $7.2^{* * *}$ & $10.6^{\star \star *}$ & $8.6^{* * *}$ & $6.0^{* * *}$ & $4.9^{* * *}$ & 1.6 n.s. & $5.4^{* * *}$ & $10.2^{* * *}$ \\
\hline
\end{tabular}

$\S$ First batch of larvae; ${ }^{@}$ second batch 


\section{Table 4}

Comparison of microbial community profiles between samples from the three hatcheries. Statistical analysis by NPMANOVA based on the Bray-Curtis similarity index (pairwise Bonferroni corrected $P$ values, and $P$ levels indicated with asterisks).

\begin{tabular}{lccc}
\hline Stage & $2-3$ dph & 10 dph & 15 dph \\
\hline 2009 & - & - & - \\
Palavas/Mazarrón (Gel I) & $0.02-0.04^{*}$ & - & - \\
Palavas/Mazarrón (Gel II) & $0.002^{* *}$ & - & - \\
\hline 2010 & & & - \\
Palavas/Mazarrón (Gel III) & $0.0006^{* * *}$ & - & - \\
Palavas/Heraklion (Gel III) & $<0.0001^{* * *}$ & - & - \\
Mazarrón /Heraklion (Gel III) & $0.003^{* *}$ & - & - \\
Palavas/Mazarrón (Gel XI) & - & $0.0006^{* * *}$ & - \\
Palavas/Heraklion (Gel XI§) & - & $0.002^{* *}$ & $0.0006^{* * *}$ \\
Mazarrón /Heraklion (Gel XI§) & - & $0.02^{*}$ & \\
Palavas/Mazarrón (Gel X) & - & & \\
\hline
\end{tabular}

$\S$ Other Bonferroni corrected $P$ values: 'Palavas' vs. 'Heraklion, pseudo green': $0.005^{\star *}$;

‘Palavas' vs. 'Heraklion, mesocosm': 0.01**; 'Mazarrón' vs. 'Heraklion, pseudo green’: 0.04*; ‘Mazarrón' vs. 'Heraklion, mesocosm': 0.07 n.s. 


\section{Table 5}

Comparison of microbial community profiles between samples representing different developing stages of tuna larvae. Statistical analysis by NPMANOVA based the Bray-Curtis similarity index (pairwise Bonferroni corrected $P$ values, and $P$ levels are indicated with asterisks).

\begin{tabular}{|c|c|c|c|}
\hline Hatchery & Palavas & Mazarrón & Heraklion \\
\hline \multicolumn{4}{|l|}{2009} \\
\hline $3 \mathrm{dph} / 7 \mathrm{dph}$ (Gel XIV) & $0.0002^{* * * *}$ & - & - \\
\hline $3 \mathrm{dph} / 12 \mathrm{dph}(\mathrm{Gel} \mathrm{I})$ & - & 0.06 n.s. & - \\
\hline \multicolumn{4}{|l|}{2010} \\
\hline 2 dph/10 dph (Gel VIII) & $0.0006^{* * *}$ & - & - \\
\hline 2 dph/10 dph (Gel XIII) & $0.003^{* *}$ & - & - \\
\hline 2 dph/15 dph (Gel VIII) & $0.005^{\star *}$ & - & - \\
\hline 10 dph/15 dph (Gel VIII) & $0.008^{* *}$ & - & - \\
\hline 3 dph/20 dph (Gel VI) & - & 0.2 n.s. ${ }^{\S}$ & - \\
\hline 10 dph/15 dph (Gel VII) & - & $0.002^{* *}$ & - \\
\hline $3 \mathrm{dph} / 10 \mathrm{dph}$ (pseudo green, Gel IV) & - & - & $0.0009^{* * *}$ \\
\hline $3 \mathrm{dph} / 10 \mathrm{dph}$ (mesocosm, Gel IV) & - & - & $0.001^{* *}$ \\
\hline
\end{tabular}

$\S$ Not significant; the differences between intermediary stages were not significant either 
Table 6

Comparison of microbial community profiles in samples from the two consecutive years in Palavas and Mazarrón. Statistical analysis by NPMANOVA based the Bray-Curtis similarity index (pairwise Bonferroni corrected $P$ values, and $P$ levels are indicated with asterisks).

\begin{tabular}{|c|c|c|}
\hline Hatchery & Palavas & Mazarrón \\
\hline ‘09(3dph) $)^{\S / ‘ 10 ~(2 ~ d p h, ~ G e l ~ X I I I) ~}$ & $0.002-0.004^{* *}$ & - \\
\hline ‘09/‘10 (3 dph, Gel IX) & - & $<0.0001^{* * *}$ \\
\hline ‘09(12 dph)/‘10 (10 dph, Gel VII) & - & $0.0006^{* * *}$ \\
\hline ‘09(12 dph)/‘10 (15 dph, Gel VII) & - & $0.007^{* *}$ \\
\hline
\end{tabular}

$\S$ Significant dissimilarity between the two batches in '09 $\left(P=0.01^{*}\right)$ 
Table 7

Spatio-temporal variations of the indices of microbial diversity in individual larva. Data are given as a function of developmental stage for the two years of investigation in the three hatcheries ('09 or '10; means \pm standard errors). The mean band richness is based on the presence of bands detected per individual, whereas the other indices of diversity were computed from relative peak intensities. Tests for significant differences between two means were done with t-test or Mann-Whitney test (MW), or in case of multiple comparisons with ANOVA followed by Tukey multiple comparison test, or with Kruskal-Wallis test (KW) followed by Dunn test. The type of test used depended on the normality and the equality of variance assumptions for the parametric tests. $P$ levels are indicated with asterisks (n.s.: not significant). For each comparison the means without common superscript are significantly different. 
Table 7

\begin{tabular}{|c|c|c|c|c|c|c|}
\hline Stage & Group & Replicates & Dominance & Band richness & Shannon & Evenness \\
\hline & Palavas ' $09^{\S}$ & 14 & $0.26^{a} \pm 0.02$ & $16.8^{\mathrm{ab}} \pm 0.7$ & $2.05^{b} \pm 0.07$ & $0.49^{c} \pm 0.03$ \\
\hline & Palavas '10 & 9 & $0.15^{b} \pm 0.01$ & $19.5^{\mathrm{a}} \pm 0.8$ & $2.61^{a} \pm 0.04$ & $0.72^{\mathrm{a}} \pm 0.02$ \\
\hline & Mazarrón '09 & 6 & $0.23^{\mathrm{ab}} \pm 0.01$ & $13.5^{b} \pm 0.6$ & $2.05^{b} \pm 0.03$ & $0.59^{b c} \pm 0.01$ \\
\hline & Mazarrón '10 & 20 & $0.18^{\mathrm{b}} \pm 0.01$ & $17.7^{\mathrm{ab}} \pm 0.9$ & $2.43^{\mathrm{a}} \pm 0.07$ & $0.67^{\mathrm{ab}} \pm 0.03$ \\
\hline & & & $\mathrm{KW}^{* \star *}$ & $\mathrm{KW}^{* *}$ & ANOVA $^{* \star *}$ & ANOVA $^{* * *}$ \\
\hline $7 \mathrm{dph}$ & Palavas ' $09^{\S}$ & 14 & $0.27 \pm 0.03$ & $15.8 \pm 1.2$ & $1.93 \pm 0.11$ & $0.46 \pm 0.03$ \\
\hline \multicolumn{7}{|l|}{$10 \mathrm{dph}$} \\
\hline & Palavas '10 & 10 & $0.15^{b} \pm 0.02$ & $20.0^{a} \pm 0.5$ & $2.59^{\mathrm{a}} \pm 0.06$ & $0.69^{\mathrm{a}} \pm 0.02$ \\
\hline \multicolumn{7}{|l|}{$15 \mathrm{dph}$} \\
\hline & Palavas '10 & 16 & $0.13^{b} \pm 0.01$ & $19.9^{a} \pm 0.9$ & $2.75^{\mathrm{a}} \pm 0.05$ & $0.82^{\mathrm{a}} \pm 0.03$ \\
\hline & Mazarrón '10 & 7 & $0.16^{a} \pm 0.02$ & $15.3^{b} \pm 0.4$ & $2.39^{b} \pm 0.06$ & $0.73^{\mathrm{a}} \pm 0.04$ \\
\hline & & & $\mathrm{MW}^{*}$ & $\mathrm{MW}^{* *}$ & $\mathrm{MW}^{* * *}$ & $t(n . s)$. \\
\hline $20 \mathrm{dph}$ & Mazarrón '10 & 2 & $0.27-0.30$ & $11-13$ & $1.74-1.88$ & $0.52-0.55$ \\
\hline
\end{tabular}

$\S$ First batch of larvae; ${ }^{@}$ second batch 